\title{
Synthesis, Spectroscopic, Molecular Modeling and Anti-Fungal Studies of Some Divalent Metal Complexes of 4-Hydroxyacetophenone Isonicotinoyl Hydrazone
}

\author{
Gwendoline M. Toh-Boyo ${ }^{1 *}$, Romanus N. Njong2 ${ }^{2}$ Estella M. Babette ${ }^{1}$, Emmanuel N. Nfor ${ }^{*}$ \\ ${ }^{1}$ Department of Chemistry, University of Buea, Buea, Cameroon \\ ${ }^{2}$ Department of Fundamental Science, Higher Technical Teachers Training College Bamenda, Bambili, Cameroon \\ Email: ^nfor.emmanuel@ubuea.cm, ${ }^{\star}$ gwendoline.mochia@ubuea.cm
}

How to cite this paper: Toh-Boyo, G.M., Njong, R.N., Babette, E.M. and Nfor, E.N. (2021) Synthesis, Spectroscopic, Molecular Modeling and Anti-Fungal Studies of Some Divalent Metal Complexes of 4-Hydroxyacetophenone Isonicotinoyl Hydrazone. Open Journal of Inorganic Chemistry, 11, 95-109. https://doi.org/10.4236/ojic.2021.113007

Received: July 1, 2021

Accepted: July 23, 2021

Published: July 26, 2021

Copyright $\odot 2021$ by author(s) and Scientific Research Publishing Inc. This work is licensed under the Creative Commons Attribution International License (CC BY 4.0).

http://creativecommons.org/licenses/by/4.0/

\section{(c) (i) Open Access}

\begin{abstract}
A novel ligand N-4-hydroxyacetophenone isonicotinoyl hydrazone and its manganese(II) and nickel(II) metal complexes have been synthesized. The synthesized Schiff base and its metal complexes have been characterized by physical state determination, melting point and solubility measurements in different solvents, infrared, proton nuclear magnetic resonance, mass spectrometric and powder X-ray spectroscopic techniques. The thermal properties of the prepared compounds were obtained from TG/DTG measurements. On the basis of the analytical techniques, the ligand was found to be bidentate in nature coordinating to the metal ions through the azomethine nitrogen and carbonyl oxygen atoms leading to distorted octahedral geometries of the metal complexes which were modeled using MM2 force field. The ligand and its metal(II) complexes were evaluated for antifungal activity against Aspergillus fumigatus, Aspergillus niger, Candida albicans and Rhizopus stolonifera. The antifungal evaluation results revealed an enhanced activity upon coordination of the ligand with the metal(II) ions. The activity of the metal complex to the tested fungal strains was in the order $\mathrm{Ni}(\mathrm{II})>$ $\mathrm{Mn}(\mathrm{II})$.
\end{abstract}

\section{Keywords}

N-4-Hydroxyacetophenone Isonicotinoyl Hydrazone, Metal Complexes, Antifungal Activity, Molecular Modeling 


\section{Introduction}

Hydrazones Schiff base compounds are formed usually through the condensation reaction of stoichiometric amounts of the appropriate hydrazine/hydrazide with carbonyl compounds such as aldehydes and ketones in alcoholic solvents like ethanol [1] to yield a product with the general formula, R-CO-NH-N=CR'R" [2]. These compounds have been found to possess interesting biological properties, such as anticonvulsant [3] [4], anti-inflammatory and antimicrobial [5], anti-tuberculosis [6], antitumor [7] [8], and antiviral [9] activities. Furthermore, they are important compounds for drug design, as possible ligands for metal complexes, organo-catalysis and also for the syntheses of heterocyclic compounds [10]. In recent years, a lot of biologically important hydrazide-hydrazones derivatives have been synthesized from different carbonyl compounds [11] [12] [13] [14] [15]. The biological activities of many of these compounds have been shown to be related to their metal-chelating abilities [16] [17] [18]. Therefore this class of compounds could be a good starting point to develop new led compounds in the treatment of multidrug-resistant bacteria.

Inspired by these considerations and in continuation with our studies on hydrazones ligands [19] [20], we herein report on the synthesis, spectroscopic, molecular modeling and antifungal activity of 4-hydroxyacetophenone isonicotinoyl hydrazone nickel(II) and manganese(II) metal complexes.

\section{Materials and Method}

All the reagents and chemicals used in this work were of analytical grade and used without further purification. Perkin-Elmer spectrum 100-FT-IR spectrometer was used for functional group identification. ${ }^{1} \mathrm{H}-\mathrm{NMR}$ spectra were obtained on a variant unity plus $400 \mathrm{MHz}$ instrument. PXRD analysis was conducted using the Brucker D8 Advance for crystal structure determination and 6545 QT used for mass spectroscopy. Thermogravimetric analysis experiments were performed on a Shimadzu simultaneous TGA/DTG-60A compositional analysis instrument and the GallenKampe melting point apparatus fitted with a mercury-in-glass thermometer having a temperature range of $10^{\circ} \mathrm{C}$ to $360^{\circ} \mathrm{C}$ was used for melting point determination.

\subsection{Synthesis of 4-Hydroxyacetophenone Isonicotinoyl Hydrazone}

A solution of 4-hydroxyacetophenone $(1.36 \mathrm{~g}, 0.01 \mathrm{~mol})$ in $15 \mathrm{~mL}$ of methanol as solvent was added to a solution of isoniazid $(1.37 \mathrm{~g}, 0.01 \mathrm{~mol})$ in $15 \mathrm{~mL}$ methanol. Three drops of glacial acetic acid were added to the resulting mixture and refluxed for 6 hours at a temperature of $70^{\circ} \mathrm{C}$. On cooling, the precipitate was filtered and washed several times with methanol and dried over $\mathrm{CaCl}_{2}$ in a desiccator. Percentage yield was $84.2 \%$ (Scheme 1).

\subsection{Synthesis of Manganese(II) Complex}

The ligand $(0.286 \mathrm{~g}, 1.12 \mathrm{mmol})$ dissolved in $10 \mathrm{~mL}$ of methanol was added to 


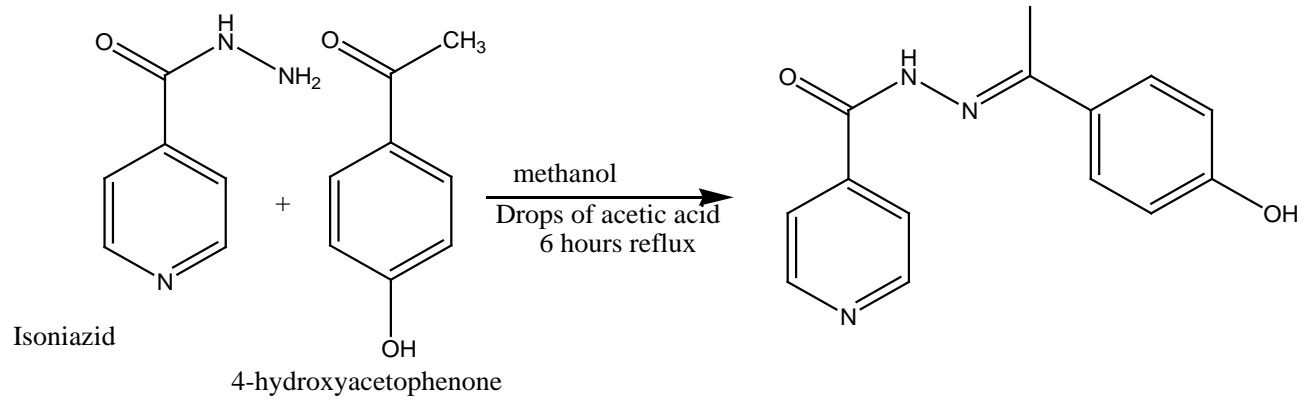

Scheme 1. Synthesis of ligand 4-hydroxyacetophenone isonicotinoyl hydrazone.

$\mathrm{Mn}(\mathrm{Cl})_{2} \cdot 4 \mathrm{H}_{2} \mathrm{O}(0.197 .6 \mathrm{~g}, 0.559 \mathrm{mmol})$ dissolved in $10 \mathrm{~mL}$ of methanol. Three drops of glacial acetic acid were added to the mixture and refluxed at a temperature of $70^{\circ} \mathrm{C}$ for 5 hours. On cooling, a yellow precipitate was filtered and washed several times with methanol and dried over $\mathrm{CaCl}_{2}$ in a desiccator. Percentage yield $86.7 \%$.

\subsection{Synthesis of Nickel(II) Complex}

The ligand $(0.286 \mathrm{~g}, 1.12 \mathrm{mmol})$ dissolved in $10 \mathrm{~mL}$ of methanol was added to $\mathrm{NiCl}_{2}(0.0724 \mathrm{~g}, 0.559 \mathrm{mmol})$ dissolved in $10 \mathrm{~mL}$ of methanol followed by the addition of three drops of glacial acetic acid. The resulting mixture was refluxed at a temperature of $70^{\circ} \mathrm{C}$ for 5 hours. On cooling, a greenish-white precipitate was filtered and washed several times with methanol and dried over $\mathrm{CaCl}_{2}$ in a desiccator. Percentage yield $74.8 \%$.

\subsection{Solubility Test}

About $0.1 \mathrm{~g}$ of the ligand and complexes were added separately to $1 \mathrm{~mL}$ portion of the following solvents; ethanol, methylene chloride, distilled water, DMSO, and hexane, then shaken vigorously upon each addition. When all solute particles dissolved to form a homogeneous mixture, the compound was said to be very soluble in the solvent. If only part of the solute dissolved, the compound was said to be sparingly soluble in the solvent. If the solute remained unaffected after agitation in the solvent, then the compound was said to be insoluble in the solvent.

\subsection{Antifungal Test for the Ligand and Its Metal(II) Complexes}

The antifungal activities of the compounds were evaluated in vitro against the fungal strains: Aspergillus fumigatus, Aspergillus niger, Candida albicans and Rhizopus stolonifera cultured on Sabouraud dextrose agar seeded with $10^{5} \mathrm{~mL}^{-1}$ fungal spore suspension and transferred to petri plates. Discs soaked in $20 \mathrm{~mL}$ $(10 \mu \mathrm{g} / \mathrm{mL}$ in DMSO) of all compounds were placed at different positions on the agar surface. The plates were incubated at $32^{\circ} \mathrm{C}$ for 7 days. The results were recorded as zones of inhibition in $\mathrm{m}$ and compared with the standard drug Nystatine. In order to clarify any participating role of DMSO in the biological screening, separate studies were carried out with the solutions of DMSO alone and they showed no activity against any fungal strains [21]. 


\section{Results and Discussion}

\subsection{Physical Properties of Ligand and Its Metal(II) Complexes}

Table 1 shows the physical properties of the ligand and its metal complexes. The colours were all intense and different from those of the metal salts used. The high melting points $\left(265^{\circ} \mathrm{C}\right.$ to $\left.290^{\circ} \mathrm{C}\right)$ suggest the compounds exist in some polymeric forms and all melt with decomposition by apparent colour changes. All the prepared compounds were insoluble in methylene chloride, hexane and distilled water, sparingly soluble in ethanol and very soluble in DMSO.

\subsection{Spectral Analysis of Ligand and Its Metal(II) Complexes}

\subsubsection{Mass Spectra}

The ESI-Mass spectrum of the ligand (Figure 1) showed the molecular ion peak $[\mathrm{M}+\mathrm{H}]^{+}$at $\mathrm{m} / \mathrm{z} 256$ confirming the exact molecular weight of the ligand at $\mathrm{m} / \mathrm{z}$ 255. The ESI mass spectrum for the manganese(II) complex showed a peak at $\mathrm{m} / z 311$ due to $[\mathrm{M}+\mathrm{H}]^{+1}$ which confirmed its exact molecular weight at $\mathrm{m} / z 310$. With the nickel(II) complex, the spectrum exhibited a peak at $\mathrm{m} / z 314$ due to $[\mathrm{M}+\mathrm{H}]^{+1}$ confirming the molecular weight at $\mathrm{m} / z 313$.

\subsubsection{Infrared Spectra}

In the IR spectrum of the ligand (Figure 2), the formation of the Schiff base is confirmed due to the presence of a broad signal of a secondary amide $(\mathrm{NH})$ at $3300 \mathrm{~cm}^{-1}$ [22]. A strong band at $1665 \mathrm{~cm}^{-1}$ indicates the presence of an amide I carbonyl band in the ligand [23]. The band at $1545 \mathrm{~cm}^{-1}$ is assigned to $\mathrm{N}-\mathrm{H}$ moiety [24] [25]. The band at $1020 \mathrm{~cm}^{-1}$ is identified the presence of $\mathrm{N}-\mathrm{N}$ group.

The Infrared spectra of the manganese(II) and nickel(II) complexes (Figure 3 \& Figure 4) show abroad band signal of a secondary amide (NH) in the 3275 $3300 \mathrm{~cm}^{-1}$ as observed in the ligand spectrum precluding the possibility of complexation through the imine-nitrogen atom [25] [26]. A relatively strong band at $1653 \mathrm{~cm}^{-1}$ and $1665 \mathrm{~cm}^{-1}$ in the $\mathrm{Ni}(\mathrm{II})$ and $\mathrm{Mn}$ (II) complexes respectively indicates coordination through the carbonyl oxygen atom of the free base [23] [25]. The absorption band at $1545 \mathrm{~cm}^{-1}$ in both complexes was assigned to $\mathrm{NH}$ moiety as in the ligand confirming that the $\mathrm{NH}$ group does not take part in coordination [24] [25]. The band at $1020 \mathrm{~cm}^{-1}$ and $1040 \mathrm{~cm}^{-1}$ for the $\mathrm{Mn}$ (II) and $\mathrm{Ni}(\mathrm{II})$ complexes respectively was assigned to the $\mathrm{N}-\mathrm{N}$ group. The shift to higher wave number in the nickel complex is very characteristic for many hydrazine ligands coordinating through the azomethine nitrogen atom which is as a result of the repulsion between the lone pairs of electrons on the adjacent nitrogen atoms, reduced after complexation [27] [28].

Table 1. Physical Properties of the Schiff Base and its Metal(II) Complexes.

\begin{tabular}{ccccc}
\hline Compound & Physical State & Colour & \%Yield & Melting Point $/{ }^{\circ} \mathrm{C}$ \\
\hline $\mathrm{C}_{14} \mathrm{H}_{13} \mathrm{~N}_{3} \mathrm{O}_{2}$ & Powdery & Yellow & 84.2 & $285-290$ \\
$\mathrm{Mn}\left(\mathrm{C}_{14} \mathrm{H}_{13} \mathrm{~N}_{3} \mathrm{O}_{2}\right)_{2}(\mathrm{Cl})_{2}$ & Powdery & Yellow & 86.78 & $285-290$ \\
$\mathrm{Ni}\left(\mathrm{C}_{14} \mathrm{H}_{13} \mathrm{~N}_{3} \mathrm{O}_{2}\right)_{2}(\mathrm{Cl})_{2}$ & Powdery & Grey & 74.78 & $265-270$ \\
\hline
\end{tabular}




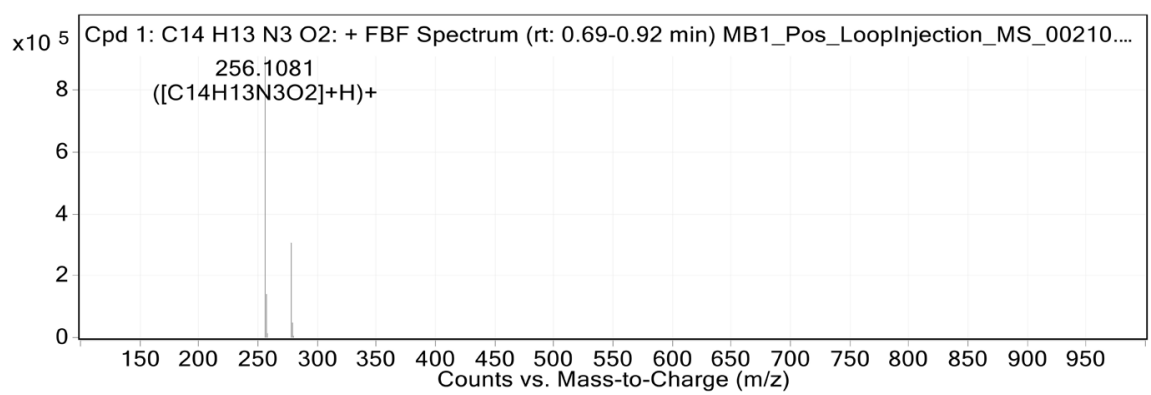

Figure 1. Mass spectrum of the ligand.

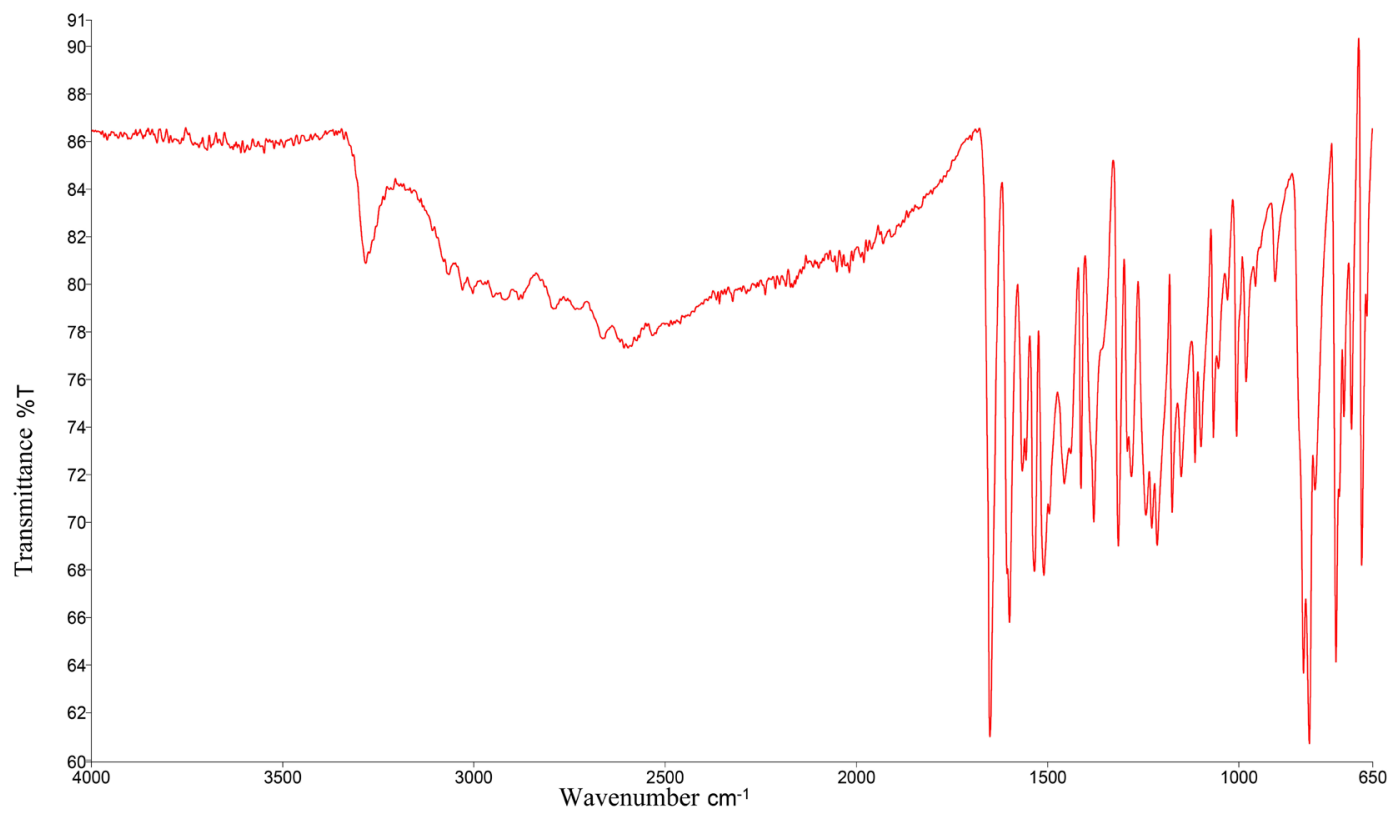

Figure 2. IR spectrum of the ligand.

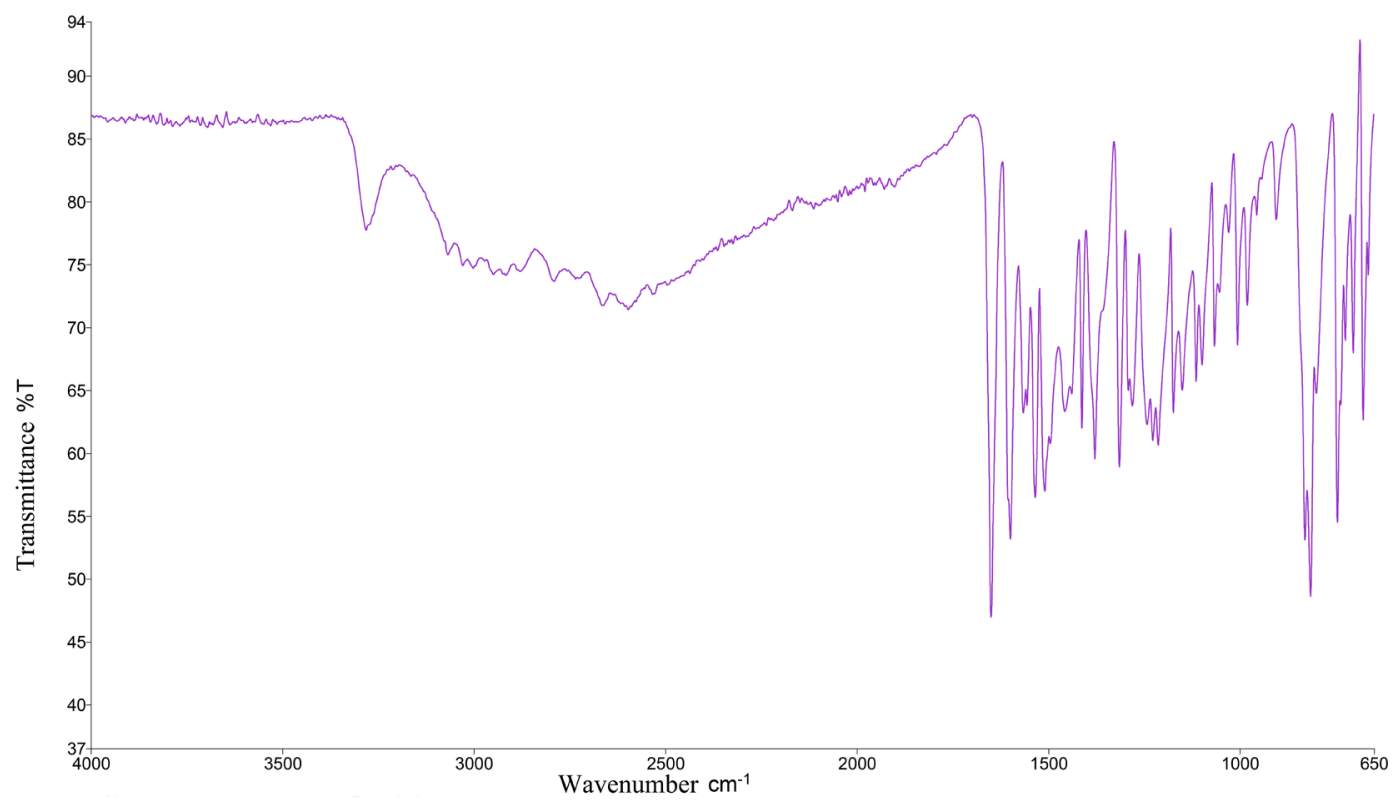

Figure 3. IR spectrum of the Mn(II) complex. 


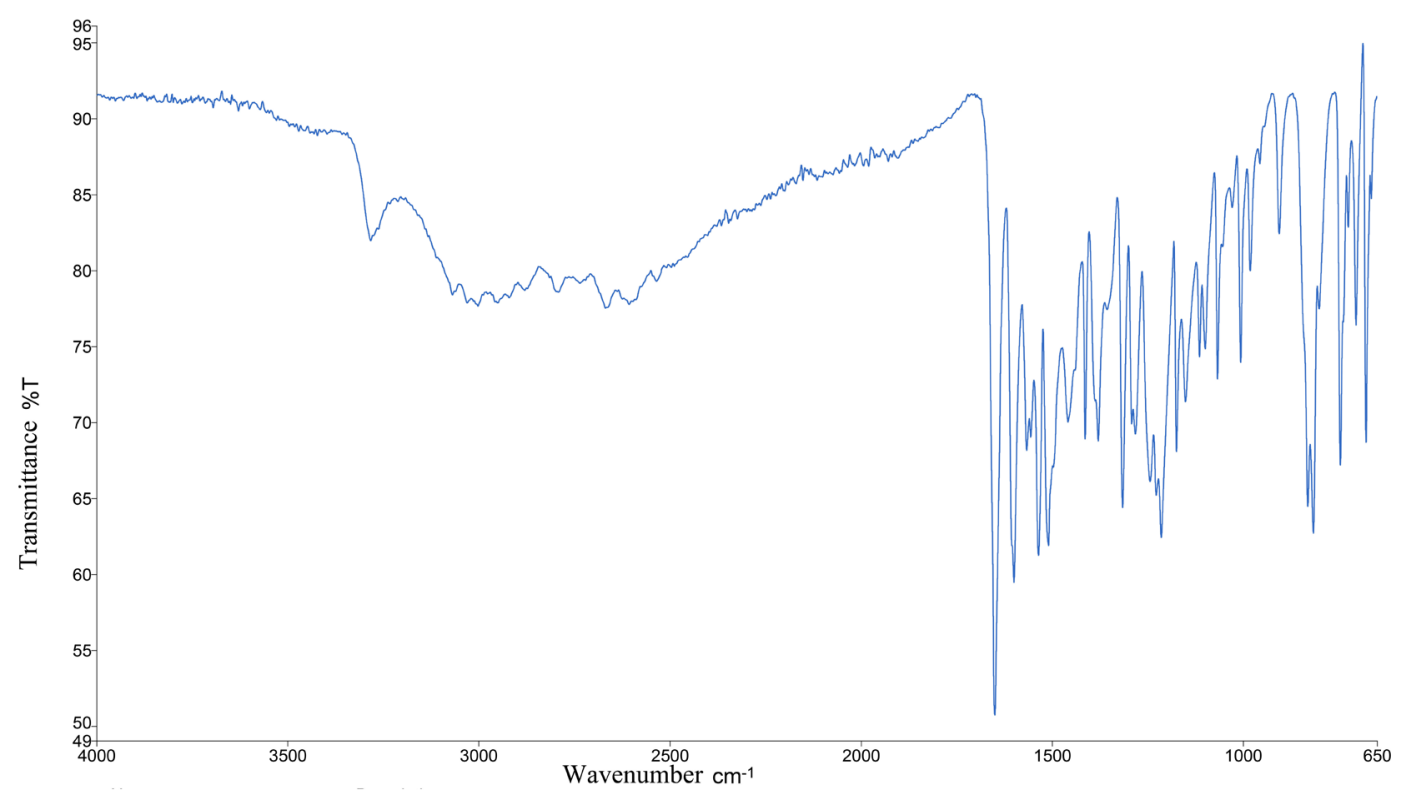

Figure 4. IR spectrum of the $\mathrm{Ni}(\mathrm{II})$ complex.

\subsubsection{Proton-NMR}

The $\mathrm{H}^{1}$ NMR analysis of the ligand in DMSO solution had seven intense peaks as shown in Figure 5. The peak at $2.31 \mathrm{ppm}$ is assigned to the methyl protons. The multiplets at 6.83 and $7.78 \mathrm{ppm}$, and 7.80 and $8.76 \mathrm{ppm}$ are assigned to methine protons (Aryl-C-H) on the phenyl ring and the pyridyl (Py-C-H) protons respectively [24]. The peak at $10.91 \mathrm{ppm}$ is due to the highly deshielded hydroxyl proton (Aryl-OH) on the benzene ring while the peak at $9.84 \mathrm{ppm}$ is assigned to the highly deshielded proton of the imino group (CON-H) involved in hydrogen bond formation since in solution the ligand exist in the keto-enol form with the enolic form being dominant and highly deshielded [29].

\subsection{TG/DTG Analysis of Ligand and Its Metal(II) Complexes}

Thermogravimetric (TG) and differential thermogravimetric analyses (DTG) were carried out for the ligand in $\mathrm{N}_{2}$ atmosphere at atemperature range 40 to $800^{\circ} \mathrm{C}$ at the heating rate of $10^{\circ} \mathrm{C} \cdot \mathrm{min}^{-1}$. The data from TG and DTG clearly indicated that the decomposition of the ligand proceeds in one step. The weight losses for each complex were calculated within the corresponding temperature ranges [30]. The TG curve of the ligand as shown in Figure 6 indicated a 81.31\% weight loss in a single step that starts around $285^{\circ} \mathrm{C}$ to $450^{\circ} \mathrm{C}$. The DTG showed an inflation point of $311^{\circ} \mathrm{C}$ representing the exact decomposition temperature.

The data from the TG and DTG curves for $\mathrm{Mn}$ (II) and Ni(II) complexes (Figure 7 \& Figure 8) clearly indicate that the decomposition proceeds in one and three steps respectively. The weight losses for each complex were calculated within the corresponding temperature ranges [30] [31]. The manganese complex was stable up to $250^{\circ} \mathrm{C}$ but started decomposing around $260^{\circ} \mathrm{C}$ up to $450^{\circ} \mathrm{C}$ in a single step with the percentage weight loss of $78.97 \%$. Its DTG curve showed an inflation point of $298^{\circ} \mathrm{C}$. The TG curve of the nickel complex exhibits a number of de- 
composition stages and this is confirmed by numerous inflation points on its DTG as shown in Figure 8. The first stage with estimated mass loss of $3.17 \%$ within the temperature range $75^{\circ} \mathrm{C}$ to $160^{\circ} \mathrm{C}$ corresponding to the loss of hydrochloric acid molecules. It DTG showed an inflation of $98^{\circ} \mathrm{C}$. While the second step goes from $245^{\circ} \mathrm{C}$ to $380^{\circ} \mathrm{C}$ with a mass loss of $53.46 \%$ corresponding to the loss of parts of the ligand with an inflation point of $275^{\circ} \mathrm{C}$, the third step goes from $380^{\circ} \mathrm{C}$ to $560^{\circ} \mathrm{C}$ with a mass loss of $42.18 \%$ with an inflation point of $465^{\circ} \mathrm{C}$. The DTG curve showed another inflation point at $500^{\circ} \mathrm{C}$ marking the last decomposition step [30] [31].

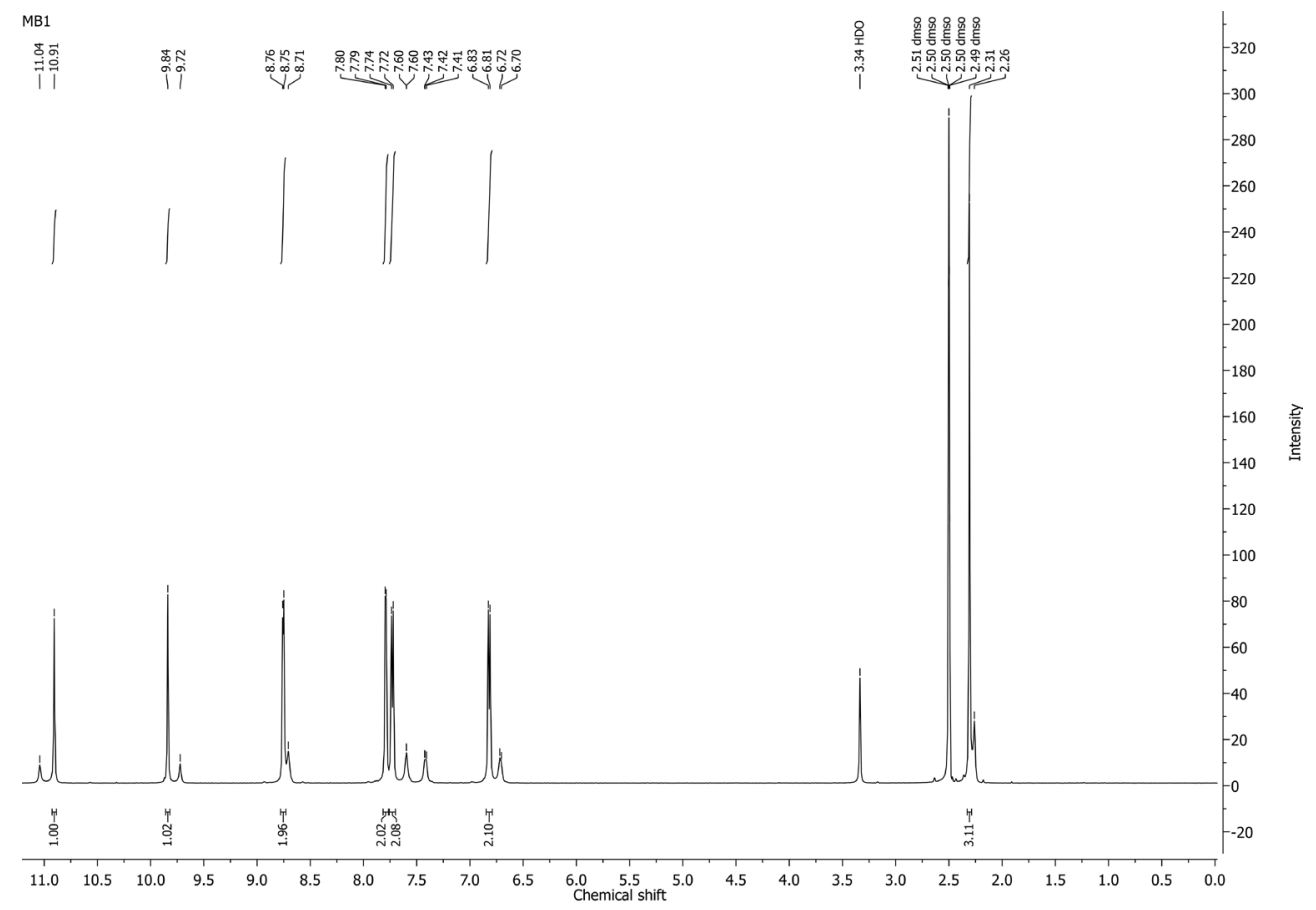

Figure 5. Proton NMR spectrum of the ligand.

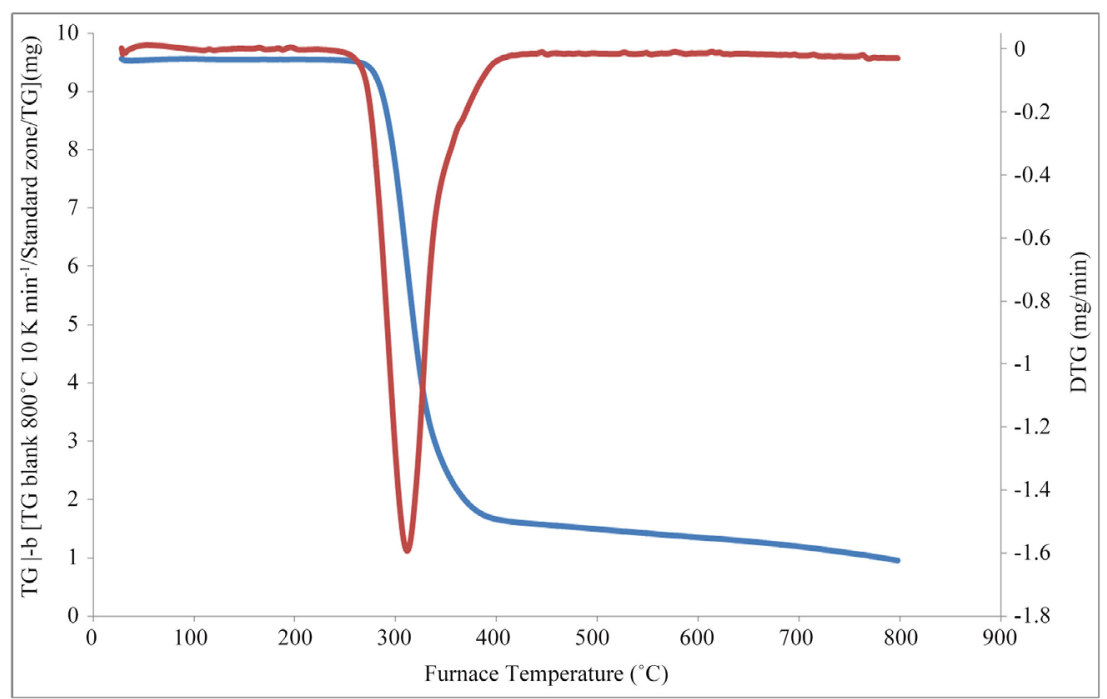

Figure 6. TG/DTG curve of ligand. 


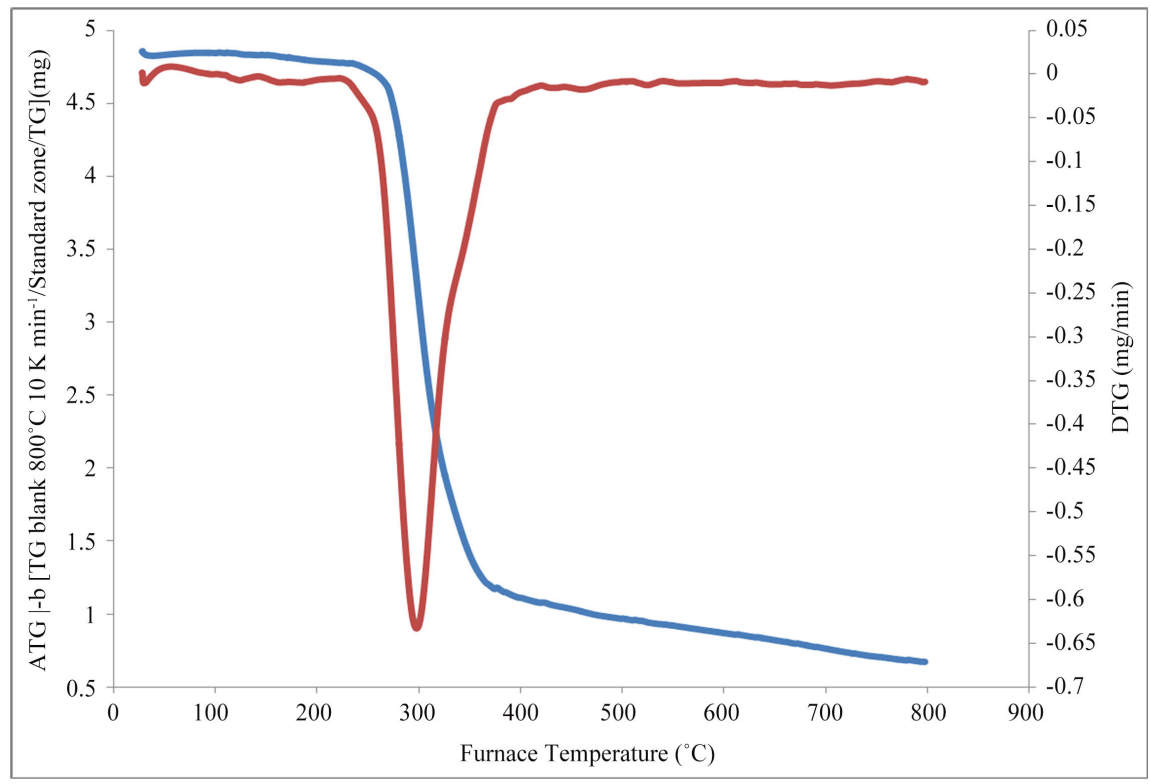

Figure 7. TG/DTG curve of Mn(II) complex.

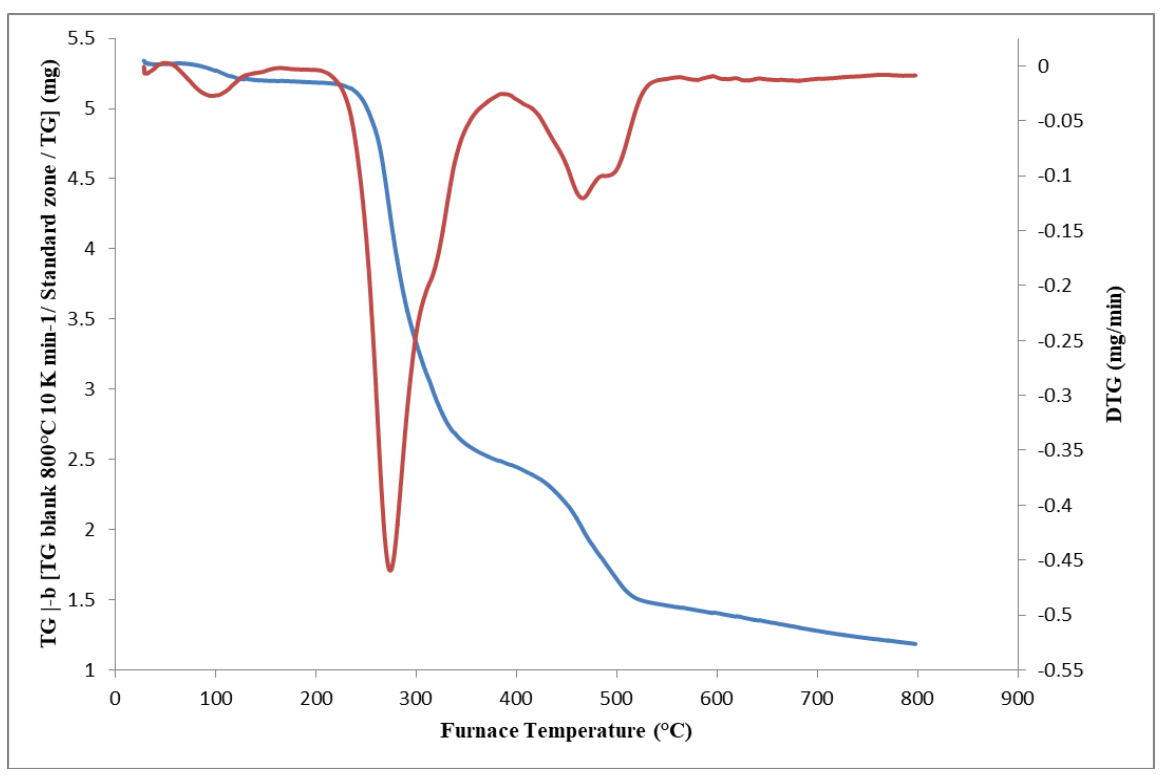

Figure 8. TG/DTG curve of $\mathrm{Ni}(\mathrm{II})$ complex.

\subsection{Powder X-Ray Diffraction of Ligand and Its Metal(II) Complexes}

Inorder to test the degree of crystallinity of the metal complexes, powder X-ray diffraction pattern were recorded using $\mathrm{CuKa}$ (wave length of 1.5406), as source in the range $4^{\circ}-60^{\circ}(2 \theta)$. In both ligand and the metal complexes, the trend of the curves (Figures 9-11) decreases from maximum to minimum intensity indicating the amorphous nature of the complexes in the metal-ligand formation [32]. The X-ray diffraction pattern of $\mathrm{Ni}(\mathrm{II})$ complex recorded numerous reflections between the range $4^{\circ}-60^{\circ}(2 \theta)$, which arouse from diffraction of X-ray by the plane of the complex from which 10 were chosen. The inter-planar spacing 


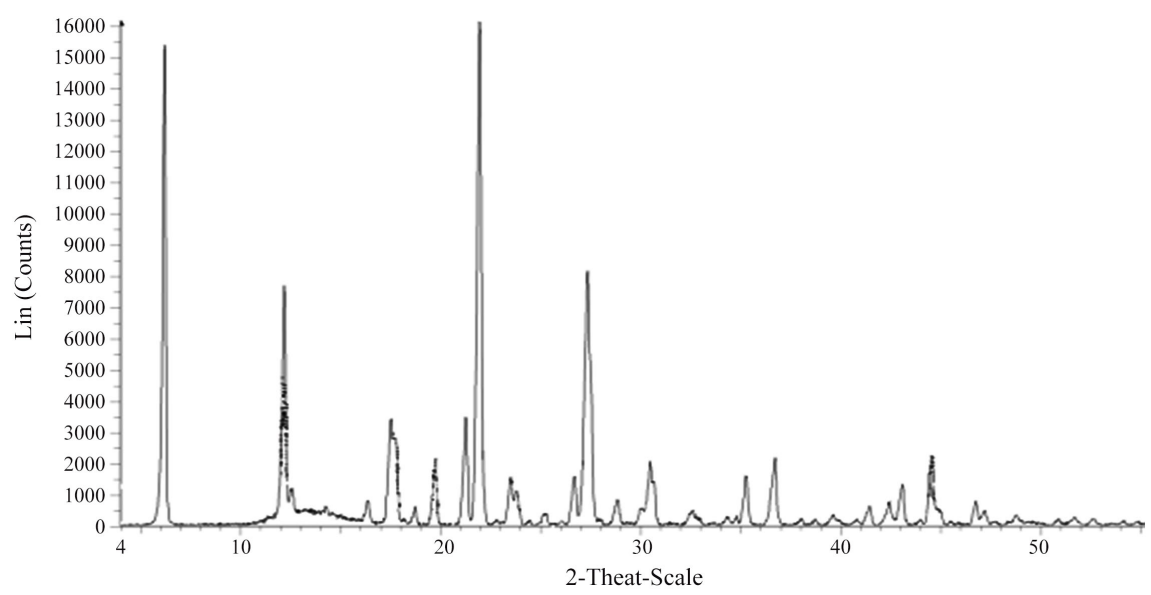

Figure 9. Powder X-ray spectrum of the ligand.

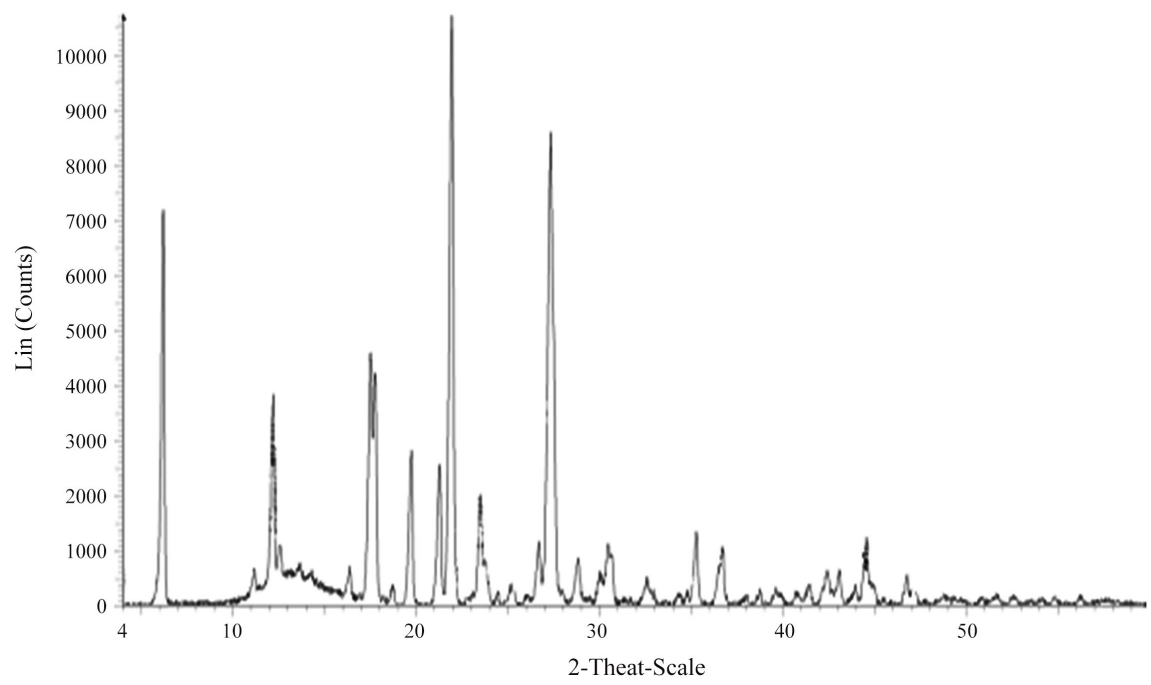

Figure 10. Powder X-ray of manganese(II) complex.

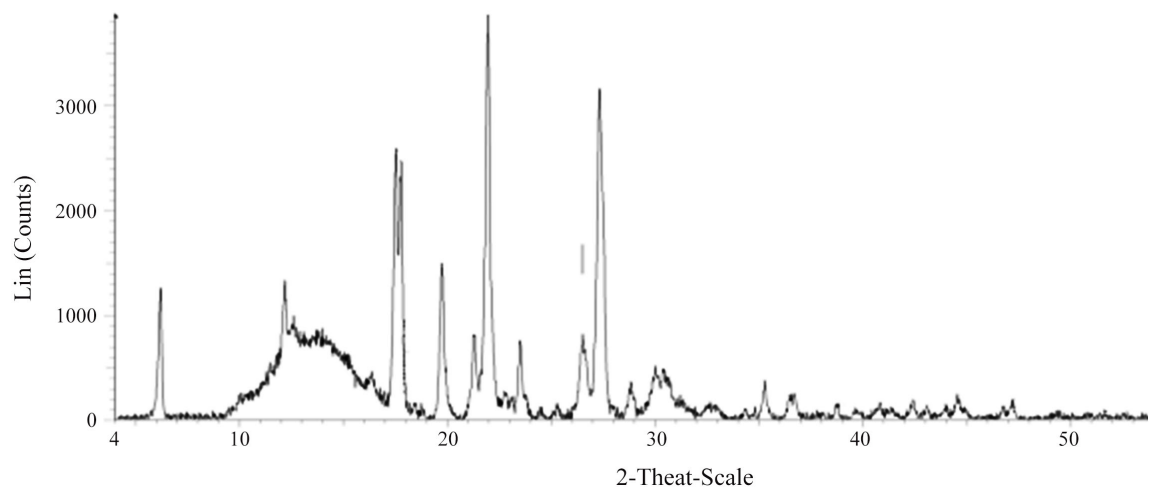

Figure 11. Powder X-ray of nickel(II) complex.

was calculated by using Bragg's equation: $n \lambda=2 d \sin \theta$. The unit cell calculations were done for cubic symmetry from all-important peaks and the method yielded $h k l$ (Miller indices) unit cell parameter values. The $h^{2}+k^{2}+P$ values for the $\mathrm{Ni}(\mathrm{II})$ complex are $1,4,8$, and $10,15,18,32,46,56,74$. The presence of forbid- 
den number 15 was observed in the $\mathrm{Ni}(\mathrm{II})$ complex indicating that the complex may belong to the hexagonal or tetragonal systems. The $h^{2}+k^{2}+P$ values for $\mathrm{Mn}(\mathrm{II})$ complex are 1, 2, 4, 5, 6, 8, 10, 17, 26, 41 and no forbidden numbers were found for the chosen reflections.

On the basis of the infrared, proton NMR, mass spectroscopic, TG/DTG and powder X-ray diffraction analysis, the proposed structures of the ligand and its metal complexes were modeled as depicted below in Figures 12-14.

\subsection{Molecular Modelling Studies of Ligand and Its Metal(II) Complexes}

Since the single crystals structures of the ligand and its metal(II) complexes were not available, an attempt to gain more insight on the molecular structure of the complexes, geometrical optimization and conformational analysis, 3D molecular modelling of the proposed structures of the complexes was performed using MM2CS Chem3D Ultra 11.0 version software and using pm3 programme. The correct stereochemistry was assured through the exploitation and modification of the molecular coordinates to attain reasonable low energy molecular geometries. The potential energies of the complexes were considered as the sum of the following equation:

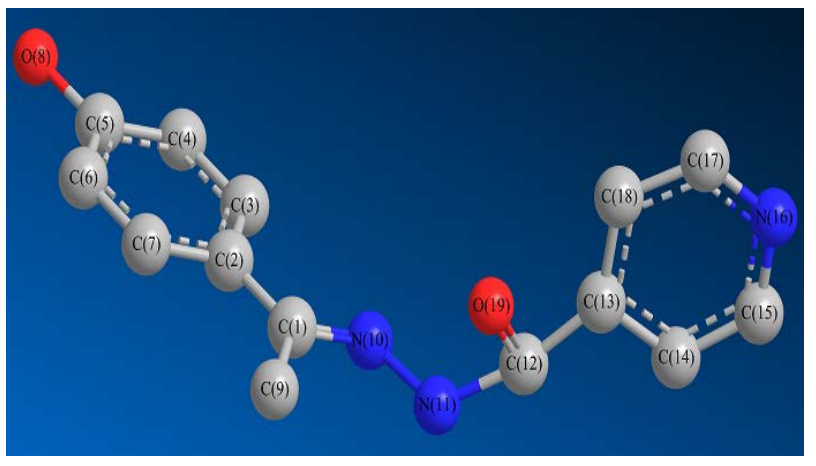

Figure 12. Optimized geometry of ligand. Hydrogen atoms are omitted for clarity.

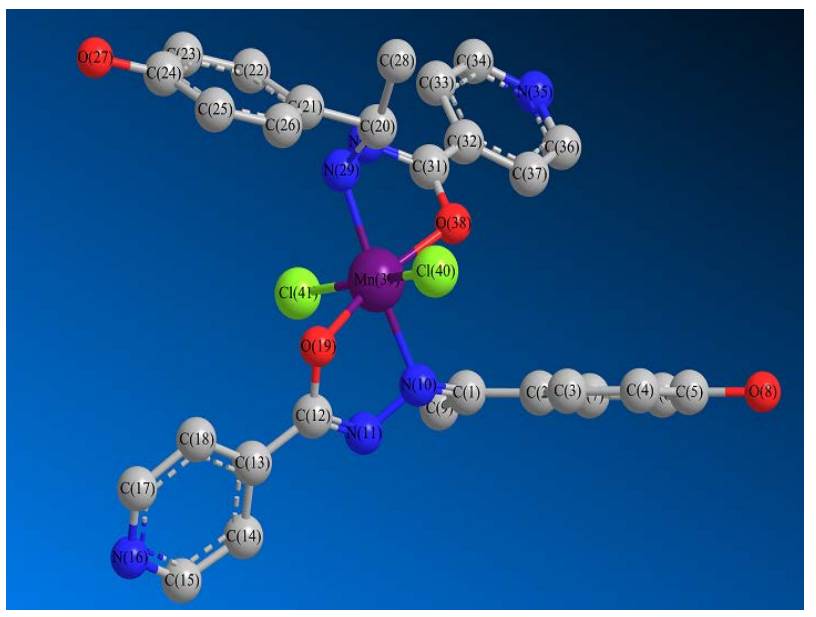

Figure 13. Optimized geometry of manganese(II) complex. 


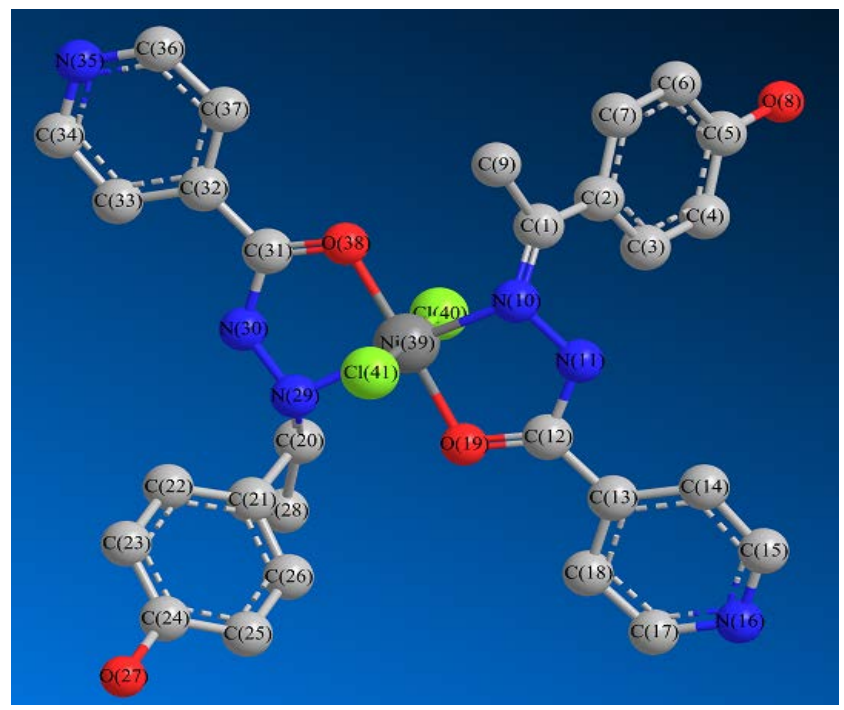

Figure 14. Optimized geometry of nickel(II) complex.

$$
E=E_{\text {str }}+E_{\text {ang }}+E_{\text {tor }}+E_{V d W}+E_{\text {oop }}+E_{\text {elec }}
$$

where $E$ represents, the energy value corresponding to the given interactions ( $\mathrm{kcal} / \mathrm{mol}$ ). The subscripts str, ang, $v d w$, oop, and elec represent bond stretching, angle boding, torsion deformation, van der Waals interaction, out of plane bending and electronic interaction respectively. The analytical and spectral studies revealed hexa-coordinated manganese and nickel complexes which were further confirm by molecular modelling studies. The 3D optimized geometrical structures of the ligand and its metal(II) complexes are presented in Figures 12-14. The minimum steric energy were repeated severally to obtain the global minimum energies of $147.314 \mathrm{kcal} / \mathrm{mol}$ for ligand and 375.801 and $1890.106 \mathrm{kcal} / \mathrm{mol}$ for manganese(II) and nickel(II) complexes respectively.

In the optimized structure of the manganese(II) complex, the $\mathrm{Mn}(39)-\mathrm{O}(19)$, $\mathrm{Mn}(39)-\mathrm{Cl}(40), \mathrm{Mn}(39)-\mathrm{N}(29)$ bond lengths are 3.8048, 1.5268, and $4.5215 \AA$ respectively. The $\mathrm{O}(38)-\mathrm{Mn}(39)-\mathrm{O}(19), \mathrm{O}(38)-\mathrm{Mn}-\mathrm{N}(29), \mathrm{O}(38)-$ $\mathrm{Mn}(39)-\mathrm{Cl}(40), \mathrm{Cl}(41)-\mathrm{Mn}(39)-\mathrm{N}(29), \mathrm{Cl}(41)-\mathrm{Mn}(39)-\mathrm{Cl}(40)$ bond angles are $167.9463^{\circ}, 29.1981^{\circ}, 96.8685^{\circ}, 118.1159^{\circ}$ and $171.9214^{\circ}$ respectively. For the optimized structure of nickel(II) complex, the $\mathrm{Ni}(39)-\mathrm{O}(19), \mathrm{Ni}(39)-\mathrm{Cl}(41)$, $\mathrm{Ni}(39)-\mathrm{N}(10)$ bond lengths are $1.8156,2.1574$ and 1.8491 Á respectively. The $\mathrm{O}(38)-\mathrm{Ni}(39)-\mathrm{O}(19), \mathrm{O}(38)-\mathrm{Ni}(39)-\mathrm{N}(29), \mathrm{O}(38)-\mathrm{Ni}(39)-\mathrm{Cl}(40), \mathrm{Cl}(41)$ - $\mathrm{Ni}(39)-\mathrm{N}(29), \mathrm{Cl}(41)-\mathrm{Ni}(39)-\mathrm{Cl}(40)$ bond angles $175.9353^{\circ}, 89.4096^{\circ}$, $87.7844^{\circ}, 83.8496^{\circ}$ and $178.5292^{\circ}$ respectively.

\subsection{Antifungal Activity}

The antifungal screening of the ligand and its metal(II) complexes was carried out against Aspergillus fumigatus, Aspergillus niger, Candida albicans and Rhizopus stolonifera according to the literature protocol. The results were compared with the standard drug Nystatine. The diameter of inhibition zones of the ligand ranged from 16 to $23 \mathrm{~mm}$ against the tested organisms, that of nickel 
Table 2. Antifungal activity of ligand and its metal complexes.

\begin{tabular}{ccccc}
\hline \multirow{2}{*}{ Compounds } & \multicolumn{4}{c}{ Diameter of zones showing complete inhibition of growth (mm) } \\
\cline { 2 - 5 } & $\begin{array}{c}\text { Aspergillus } \\
\text { fumigatus }\end{array}$ & $\begin{array}{c}\text { Aspergillus } \\
\text { niger }\end{array}$ & $\begin{array}{c}\text { Candida } \\
\text { albicans }\end{array}$ & $\begin{array}{c}\text { Rhizopus } \\
\text { stolonifera }\end{array}$ \\
\hline $\mathrm{C}_{14} \mathrm{H}_{13} \mathrm{~N}_{3} \mathrm{O}_{2}$ & 18 & 15 & 23 & 19 \\
$\mathrm{Mn}\left(\mathrm{C}_{14} \mathrm{H}_{13} \mathrm{~N}_{3} \mathrm{O}_{2}\right)_{2}(\mathrm{Cl})_{2}$ & 19.5 & 16.5 & 24.5 & 20.5 \\
$\mathrm{Ni}\left(\mathrm{C}_{14} \mathrm{H}_{13} \mathrm{~N}_{3} \mathrm{O}_{2}\right)_{2}(\mathrm{Cl})_{2}$ & 20.5 & 17.5 & 25.5 & 21.5 \\
Nystatine & 25 & 20 & 30 & 25 \\
\hline
\end{tabular}

complex from 17.5 to $25.5 \mathrm{~mm}$ and manganese complex from 19.5 to $24.5 \mathrm{~mm}$. All these values compared to that of Nystatine (reference drug) which ranged from 25 to $30 \mathrm{~mm}$ as in Table 2. This result reveals that the complexes are more reactive than their parent ligand. The order of activity of metal complexes is $\mathrm{Ni}>$ Mn. The nickel complex had the higher activity against Candida albicans (25.5 $\mathrm{mm}$ ) than manganese $(24.5 \mathrm{~mm})$ complex as compared to the ligand $(23 \mathrm{~mm})$. A similar trend was observed in the activity of metal complexes against the other fungal strands. When we compared the inhibition diameter of the ligand and the metal complexes, it was revealed that the metal complexes exhibit higher antifungal activity against the fungal strains used than the free ligand. An acceptable reason for this may be considered in the light of overtones and coordination theory proposed by [33]. According to overtone's concept of cell permeability, the lipid membrane that surrounds the cell favours the passage of only lipid soluble materials. So, liposolubility is an important factor which controls antifungal activity. On chelation, the polarity of metal ions will be reduced to a greater extend due to the overlap of the ligand and partial sharing of the positive charge of the metal ion with the donor groups.

\section{Conclusion}

The ligand, $N$-(4-hydroxylacetophenone) isonicotinoylhydrazone and its $\mathrm{Mn}$ (II) and $\mathrm{Ni}$ (II) complexes have been prepared and characterized. The melting points of the synthesized compounds were generally high and range from $260^{\circ} \mathrm{C}$ to $>300^{\circ} \mathrm{C}$ and decomposition temperatures of the metal complexes range from $250^{\circ} \mathrm{C}$ to $600^{\circ} \mathrm{C}$ revealing the stability of the metal complexes which are common to such hydrazones complexes due to coordination of ligand in different tautomeric forms. On the basis of the infrared, proton NMR, mass spectroscopic, TG/DTG and powder X-ray diffraction analysis, the ligand was found to be bidentate in nature, coordinating to the metal ions through the azomethine nitrogen and the carbonyl oxygen in a hexa-coordination mode. Antifungal screening revealed that the synthesized complexes were more active than the parent ligand.

\section{Acknowledgements}

The authors are grateful to Professor Andrew D. Burrows of the Department of Chemistry, University of Bath, Bath Spa, United Kingdom, for the assistance 
with spectroscopic measurements.

\section{Conflicts of Interest}

The authors declare no conflicts of interest regarding the publication of this paper.

\section{References}

[1] Rollas, S. and Kucukguzel, S. (2007) Biological Activities of Hydrazone Derivatives. Molecules, 12, 1910-1939. https://doi.org/10.3390/12081910

[2] Lukasz, P. (2017) Hydrazide-Hydrazones as Potential Anti-Microbial Agents; Overview of Literature since 2010. Medical Chemical Research, 26, 287-301.

[3] Violina, A., Valentin, K., Pavlina, A., Andreeva, G. and Jana, T. (2016) Recent Developments of Hydrazide/Hydrazone Derivatives and Their Analogs as Anticonvulsant Agents in Animal Models. Drug Development Research, 77, 379-392. https://doi.org/10.1002/ddr.21329

[4] Çakır, B., Dağ, Ö., Yıldırım, E., Erol, K. and Şahin, M.F. (2001) Synthesis and Anticonvulsant Activity of Some Hydrazones of 2-[(3H)-oxobenzoxazolin-3-yl-aceto]hydrazide. Eczacilik Fakultesi Dergisi-Gazi Universitesi, 18, 99-106.

[5] Kumar, V., Basavarajaswamy, G., Rai, M.V., Poojary, B., Pai, V.R., Shruthi, N. and Bhat, M. (2015) Rapid “One-Pot” Synthesis of a Novel Benzimidazole-5-carboxylate and Its Hydrazone Derivatives as Potential Anti-Inflammatory and Antimicrobial Agents. Bioorganic Medicinal. Chemistry Letters, 25, 1420-1426. https://doi.org/10.1016/j.bmcl.2015.02.043

[6] Bedia, K.K., Elcina, O., Sedaa, U., Fatmab, K., Nathaly, S., Sevima, R. and Dimoglo, A. (2006) Synthesis and Characterization of Novel Hydrazide-Hydrazone and the Study of Their Structure-Anti-Tuberculosis Activity. European Journal of Medicinal Chemistry, 41, 1253-1261. https://doi.org/10.1016/j.ejmech.2006.06.009

[7] Machakanur, S.S., Patil, B.R., Badiger, D.S., Bakale, R.P., Gudasi, K.B. and Bligh, S.W.A. (2012) Synthesis, Characterization and Anticancer Evaluation of Novel Triarm Star Shaped 1,3,5-Triazine Hydrazones. Journal of Molecular Structure, 1011, 121-127. https://doi.org/10.1016/j.molstruc.2011.12.023

[8] Nasr, T., Bondock, S. and Youns, M. (2014) Anticancer Activity of New Coumarin Substituted Hydrazide-Hydrazone Derivatives. European Journal of Medicinal Chemistry, 76, 539-548. https://doi.org/10.1016/j.ejmech.2014.02.026

[9] Şenkardes, S., Kaushik-Basu, N., Durmaz, İ., Manvar, D., Basu, A., Atalay, R. and Küçükgüzel, S.G. (2016) Synthesis of Novel Diflunisalhydrazide-Hydrazones as Anti-Hepatitis C Virus Agents and Hepatocellular Carcinoma Inhibitors. European Journal of Medicinal Chemistry, 10, 301-308.

https://doi.org/10.1016/j.ejmech.2015.10.041

[10] Nataliya, P.B., Wim, D. and Vasiliy, A.B. (2010) Synthesis and Properties of Hydrazones Bearing Amide, Thioamide and Amidine Functions. Reviews and Accounts, 2010, 275-335. https://doi.org/10.3998/ark.5550190.0011.108

[11] Dikio, C.W., Ejidike, I.P., Mtunzi, F.M., Klink, M.J. and Dikio, E. (2017) Hydrazide Schiff Bases of Acetylacetonate Metal Complexes: Synthesis, Spectroscopic and Biological Studies. International Journal of Pharmacy and Pharmaceutical Sciences, 9 , 257-267. https://doi.org/10.22159/ijpps.2017v9i12.22225

[12] Ejidike, I.P. (2018) $\mathrm{Cu}(\mathrm{II})$ Complexes of 4-[(1E)-N-\{2-[(Z)-Benzylidene-amino] ethyl\}ethanimidoyl]benzene-1,3-diol Schiff Base: Synthesis, Spectroscopic, In-Vitro 
Antioxidant, Antifungal and Antibacterial Studies. Molecules, 23, 1581. https://doi.org/10.3390/molecules23071581

[13] Velezheva, V., Brennan, P., Ivanov, P., Koronienko, A., Lyubimov, S., Kazarian, K., Nikonenko, B., Majorov, K. and Apt, A. (2016) Synthesis and Antituberculosis Activity of Indole-Pyridine Derived Hydrazides, Hydrazide-Hydrazones, and Thiosemicarbazones. Bioorganic Medici al Chemistry Letters, 26, 978-985.

https://doi.org/10.1016/j.bmcl.2015.12.049

[14] Tolan, D.A., Kashar, T.I., Yoshizawa, K. and El-Nahas, A.M. (2021) Synthesis, Spectral Characterization, Density Functional Theory Studies and Biological Screening of Some Transition Metal Complexes of Novel Hydrazide-Hydrazone Ligand of Isonicotinic Acid. Applied Organometallic Chemistry, 35, 69-75.

https://doi.org/10.1002/aoc.6205

[15] Shakdofa, M.M.E., El-Saied, F.A., Rasras, A.J. and Al-Hakimi, A.N. (2018) Transition Metal Complexes of a Hydrazone-Oxime Ligand Containing the Isonicotinoyl Moiety: Synthesis, Characterization and Microbicide Activities. Applied Organometallic Chemistry, 32, 3-17. https://doi.org/10.1002/aoc.4376

[16] Ainscough, E.W., Brodie, A.M., Denny, W.A., Finlay, G.J., Gothe, S.A. and Ranford, J.D. (1999) Cytotoxicity of Salicylaldehyde Benzoyl Hydrazone Analogs and Their Transition Metal Complexes: Quantitative Structure-Activity Relationships. Journal of Inorganic Biochemistry, 77, 125-133. https://doi.org/10.1016/S0162-0134(99)00131-2

[17] Richardson, D.R. and Bernhard, P.V. (1999) Crystal and Molecular Structure of 2-Hydroxy-1-Naphthaldehyde Isonicotinoyl Hydrazone (NIH) and Its Iron(III) Complex: An Iron Chelator with an Ti-Tumour Activity. Journal of Biological Inorganic Chemistry, 4, 266. https://doi.org/10.1007/s007750050312

[18] Zong, C.K., May, L.L. and Irene, L. (2020) Schiff Bases and Their Copper(II) Complexes Derived from Cinnamaldehyde and Different Hydrazides: Synthesis and Antibacterial Properties. Journal of Transition Metal Complexes, 3, Article ID: 236087. https://doi.org/10.32371/jtmc/236087

[19] Majoumo-Mbe, F., Nfor, E.N., Eric, B.S., Romanus, N.N. and Offiong, E.O. (2015) Synthesis, Crystal Structure and Biological Activity of 1-(phthalazin-1(2H)-one) [(Pyridin2-yl)ethylidene]hydrazone and Its Cobalt(III) Complex. Communication in Inorganic Synthesis, 3, 40-46.

[20] Majoumo-Mbe, F., Nfor, E.N., Tsobnang, P.K., Eloundou, V.B.N., Yong, J.N. and Efeti, I.I. (2019) Synthesis, Molecular and Crystal Structure of 1-(1,2-dihydrophthalazin-1-ylidene)-2-[1-(thiophen-2-yl)ethylidene] Hydrazine. Acta Crystallogaphy Section E, 75, 251-254. https://doi.org/10.1107/S2056989019000732

[21] Bauer, A., Kirby, W., Sherris, J. and Turck, M. (1966) Antibiotic Susceptibility Testing by a Standardized Single Disk Method. American Journal of Clinical Pathology, 45, 493-496. https://doi.org/10.1093/ajcp/45.4 ts.493

[22] Nfor, E.N., Husain, A., Majoumo-mbe, F., Njah, I.N., Bourne, S.A. and Effiong, E.O. (2013) Synthesis, Crystal Structure and Antifungal Activity of Ni(II) Complex of a New Hydrazone Derived from Anti-Hypertensive Drug Hydralazine Hydrochloride. Polyhedron, 63, 207-213. https://doi.org/10.1016/j.poly.2013.07.028

[23] Kalia, S., Lumba, K., Kaushal, G. and Sharma, M. (2007) Magnetic and Spectral Studies of Cobalt(II) Chelates of a Thiocarbazate Derived from Isoniazid. Indian Journal of Chemistry, 46, 1233-1239.

[24] Nfor, E.N., Esemu, S.N., Ayimele, G.A., Eno, E.A., Imama, G.E. and Effiong, E.O. (2011) Synthesis, Stereochemistry and Antimicrobial Activity of $\mathrm{Cu}(\mathrm{II})$ and $\mathrm{Ni}(\mathrm{II})$ 
Complexes of 4-Phenylsemecarbazones. Bulletin of the Chemical Society of Ethiopia, 25, 361-370. https://doi.org/10.4314/bcse.v25i3.68668

[25] Prasad, S. and Agarwal, K. (2009) Synthesis, Magneto-Spectral, Electrochemical, Thermal Characterization and Antimicrobial Investigations of Some Nickel(II) Complexes of Hydrazones of Isoniazid. Journal of the Korean Chemical Society, 53, 683-692. https://doi.org/10.5012/jkcs.2009.53.6.683

[26] Affan, M., Foo, I., Fasihuddin, B., Sim, E. and Hapipah, M. (2009) Synthesis, Structural Characterization and Toxicity Studies of Novel Organotin(IV) Complexes Derived from Benzoylacetone Isonicotinoyl Hydrazone ( ${ }_{2} \mathrm{BAS}$ ): X-Ray Crystal Structure of $\mathrm{M}_{\mathrm{e} 2} \mathrm{Sn}$ (BAS). The Malaysian Journal of Analytical Sciences, 13, 73-85.

[27] Hueso, U.F., Moreno, C.M. and Penas, C.A. (2000) Ni(II), Cu(II), Zn(II) and Cd(II) Complexes with Dinegative N,N,O-Tridentate Uracil Derived Hydrazides. Acta Chimica Slovenica, 47, 481-488.

[28] Calinescu, M., Ion, E., Moreno, C.M. and Ticuta, N. (2008) Synthesis, Spectroscopic, Antibacterial and Antifungal Studies on Copper(II) Complexes with 2-Benzoylhydrazone. Revue Roumaine de Chimie, 53, 911-919.

[29] Elham, P., Kargar, H. and Sepehri, N.R. (2015) A Study on Antitubercular and Antimicrobial Activity of Isoniazid Derivative. Zahedan Journal of Research and Medical Science, 17, 1-4. https://doi.org/10.17795/zjrms1010

[30] Dhanakodia, P. and Jayandran, M. (2018) Piperazine-Cu(II) Macrocyclic Schiff Base Complex: Synthesis, Spectral Studies. Malaysian Journal of Chemical Science, 1, 1-6.

[31] Rama, K.R.K.A., Suneetha, P., Karigar, C.S., Manjunath, N.H. and Mahendra, K.N. (2008) Cobalt(II), Ni(II), Cu(II), Zn(II), Cd(II), Hg(II), Uo2(VI) And Th(IV) Complexes from ONNN Schiff Base Ligand. Journal of Chilean Chemical Society, 53, 1653-1657. https://doi.org/10.4067/S0717-97072008000400003

[32] Yernale, N. and Bennikallu, M. (2014) Synthesis, Characterization, Antimicrobial, DNA Cleavage, and in Vitro Cytotoxic Studies of Some Metal Complexes of Schiff Base Ligand Derived from Thiazole and Quinoline Moiety. Bioinorganic Chemistry and Applications, 2014, Article ID: 314963. https://doi.org/10.1155/2014/314963

[33] Tweedy, B.G. (1964) Plant Extracts with Metal Ions as Potential Antimicrobial Agents. Phytopathology, 55, 910-918. 